DEPÓSITO LEGAL ZU2020000153

Esta publicación científica en formato digital

es continuidad de la revista impresa

ISSN 0041-8811

E-ISSN 2665-0428

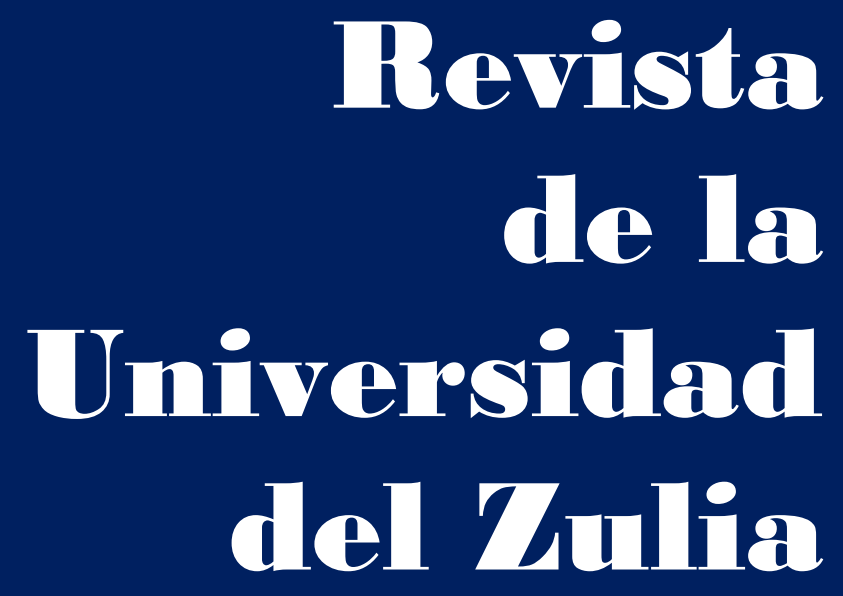

Fundada en 1947

por el Dr. Jesús Emrique Lossada

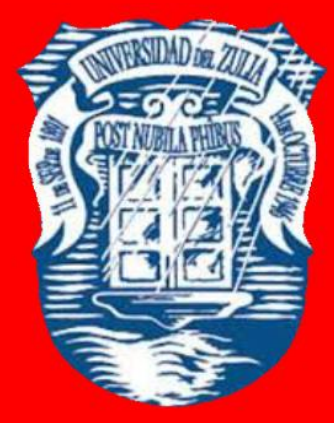

Ciencias

Sociales

y Arte

Año $12 \quad N^{\circ} 34$

Septiembre - Diciembre 2021

Tercera Época

Maracaibo-Veneruela 


\title{
Parallels of cultural renaissance and dynamics of ethnic cultures of Russia in the era of cultural globalization
}

\author{
Alexey G. Pudov * \\ Maria I. Koryakina **
}

\begin{abstract}
The objective of paper is to assess the time-compressed dynamics of the culture of the ethnonational region of Russia, to identify its regularities and to draw parallels with the stages of European and Russian cultural processes. The article identifies the quality and modernization potential of the current state of ethnic culture, which is under the pressure of assimilation of cultural globalism. The methodology is revealed by the definition of the Renaissance culture as the ability to operate with symbolic forms and the consistent transfer of the well-known properties of the European and Russian Renaissance to the modern ethnic culture of the Russian region as isomorphic processes. The paper identifies the state of regional culture as result of a double reflection of the cultural renaissance, called as the "Yakut Silver Age". The criteria for that is the presence of a creative paradigm of ethnomodernism, manifested in the field of art.

KEYWORDS: Modernization; Cultural heritage; Ethnic identity; Cultural innovations; Cultural dynamics; symbol; Modern art; arts; Russia; cinema.
\end{abstract}

*Ph.D. in Philosophy, Associate Professor, Federal State Budgetary Institution of Science Yakut Scientific Research Institute of Agriculture. ORCID: http://orcid.org/0000-0001-6215-9461. Email: agro_on_line@mail.ru

**PhD in Pedagogy, Associate Professor of the Social and Humanitarian Disciplines, Federal State Educational Institution of Higher Professional Education Arctic State Agrotechnological University. ORCID: https://orcid.org/0000-0003-1404-2642. E-mail: kormar61@mail.ru 
REVISTA DE LA UNIVERSIDAD DEL ZULIA. 3ㄹe época. Año 12 N 34, 2021

A. G. Pudov \& M. I. Koryakina// Parallels of cultural renaissance and dynamics of ethnic cultures... 535-557

DOI: http://dx.doi.org/10.46925//rdluz.34.29

\section{Paralelismos del renacimiento cultural y la dinámica de las culturas étnicas de Rusia en la era de la globalización cultural}

RESUMEN

El objetivo del trabajo consiste en evaluar la dinámica comprimida en el tiempo de la cultura de la región etnonacional de Rusia, identificar sus regularidades y establecer paralelismos con las etapas de los procesos culturales europeos y rusos. El artículo identifica la calidad y el potencial de modernización del estado actual de la cultura étnica, que está bajo la presión de la asimilación del globalismo cultural. La metodología se revela por la definición de la cultura renacentista como la capacidad de operar con formas simbólicas y la transferencia consistente de las propiedades bien conocidas del Renacimiento europeo y ruso a la cultura étnica moderna de la región rusa como procesos isomorfos. El documento identifica el estado de la cultura regional como resultado de un doble reflejo del renacimiento cultural, llamado como la "Edad de Plata Yakut". El criterio para ello es la presencia de un paradigma creativo del etnomodernismo, manifestado en el campo del arte.

PALABRAS CLAVE: Modernización; Patrimonio cultural; Identidad étnica; Innovaciones culturales; Dinámica cultural; símbolo; Arte moderno; artes; Rusia; cine.

\section{Introduction}

The subject of the research is the cultural process in the ethno-national regions of Russia, its dynamics, the current state and the possibilities of future modernization transformations. The author problematizes the issues of contact interaction of cultures, studied on the basis of the phenomenon of cultural renaissance, drawing parallels between the European Renaissance, the late Renaissance of Russian culture, the so-called Russian Silver Age and the closely studied cultural processes in the national regions of Russia, such as the Republic of Sakha (Yakutia). Taking into account the methodology of contact cultural renaissance developed by Russian philosophers and culturologists, the author of paper sets the task of transferring and adapting this methodology to the level of national regions of Russia. This problem, which is promising for the philosophy of culture, has not yet been solved by Russian anthropology for the case of processes in ethnocultural regions that have gone through a fleeting and unique way of inorg anic 
REVISTA DE LA UNIVERSIDAD DEL ZULIA. 3ㄹe época. Año $12 \mathrm{~N}^{\circ}$ 34, 2021

A. G. Pudov \& M. I. Koryakina// Parallels of cultural renaissance and dynamics of ethnic cultures... 535-557

DOI: http://dx.doi.org/10.46925//rdluz.34.29

modernization at the end of the 19th and throughout the 20th centuries. To date, no detailed assessment of the results of inorganic modernization of ethnocultural regions has been carried out on the example of the state of their art, which makes it possible to notice the contact transfer of cultural achievements. This task is explicated in detail on the example of the cultural paradigm "ethnomodern" in the cinema of Yakutia.

The objective of the paper is to qualitatively assess the cultural dynamics experienced by the ethnic cultures of Russia in the era of cultural globalism, which experienced inorganic reflected modernization transformations in the 20th century. The indicated dynamics took place during the transition from the before- and pre-modern era to modernity under the influence of active European acculturation in connection with mass education, arts, science and technology. The changes that took place were fleeting. In about 200 years, the Yakuts have experienced fundamental worldview upheavals in public consciousness from myth, acquaintance with world religions, to modern culture and a model of mass culture of the global world, which did not happen to every nation.

\section{Theoretical aspects}

The work attempted to look at the Russian culture of the Silver Age more broadly, given the possibility of a contact transfer of the cultural renaissance from one culture to another. In domestic humanitarian thought, attempts to consider the cultural renaissance as a universal event were carried out by philosophers, historians, literary scholars of the Soviet era (Kulizade, 1983; Losev, 1978; Nutsubidze, 1967; Chaloyan, 1963), as well as philosophers of contemporary culture. V.I. Kondakov in book (Kondakov, 2018) notes the works of the historian and philologist of the East N.I. Konrad, who gave the term "Renaissance" a universal character inherent not only in European culture, but also in the cultures of the countries of the East, including the Far East (Konrad, 1966). Indeed, a European-centric view can narrow the understanding of the laws of historical and cultural analysis. A broad view of the phenomenon of Renaissance gives heuristics, changing ideas about the European Renaissance as a particular case of the universal phenomenon of culture on a global scale. 
REVISTA DE LA UNIVERSIDAD DEL ZULIA. 3ㄹe época. Año $12 \mathrm{~N}^{\circ}$ 34, 2021

A. G. Pudov \& M. I. Koryakina// Parallels of cultural renaissance and dynamics of ethnic cultures... 535-557

DOI: http://dx.doi.org/10.46925//rdluz.34.29

Meanwhile, the problem is to draw a parallel between the European Renaissance, the late Renaissance of Russian culture (Russian Silver Age) and cultural processes in the national regions of Russia as Yakutia (Sakha Republic). Taking into account the methodological decisions of Russian philosophers and cultural scientists, this becomes a promising task for the philosophy of culture.

According to N.A. Berdyaev, Russia at the turn of 19-20 centuries was marked by Renaissance creative redundancy, suggesting the highest rise and, at the same time, cultural overheating. Revealing the features of the "reflected" cultural renaissance, it should be noted the "multisectoral" manifestation of cultural passionarity, embodied at the beginning in symbolic forms of art - the vanguard of culture, and then in the "softwear" and "hardwear" of scientific and technical creativity. According to contemporaries of that time, "all of Russia awakened, dreamed of some fabulous, rainbow dreams" (Platonov, 1997). The term "renaissance" becomes not just a literary metaphor drawing parallels with the European Renaissance, but a logical stage (Konrad, 1966), coming after the Russian Middle Ages, continuing to stretch after the Petrine modernization.

It should be noted the methodological indistinguishability for us of the terms "Silver Age of Russian Culture" and "Russian Cultural Renaissance", "Russian Renaissance". Those criterion differences of the Russian renaissance, which are noted by some researchers (Voskresenskaya, 2015), can be described as an attempt to differentiate a homogeneous phenomenon, "formatted" by the language of aesthetics (silver age) and the language of science (cultural renaissance). The general spiritual and creative rise among the cultural elite, interested in idealistic, romantic world representations and spiritual values, naturally inexhaustible only by them on a common cultural background, expressed a turn of view of the intelligentsia on the ideas of national Russian culture and its spiritual values forgotten by political radicalism of the left intelligentsia (Voskresenskaya, 2015). It was a conditional religious, aesthetic and socio-cultural protest against the callousness emerging in Russia. In our interpretation, this is the return of the possibility of operating in a symbolic form of culture that has been distorted in the social and political life of the state. 
REVISTA DE LA UNIVERSIDAD DEL ZULIA. 3ㄹe época. Año $12 \mathrm{~N}^{\circ}$ 34, 2021

A. G. Pudov \& M. I. Koryakina// Parallels of cultural renaissance and dynamics of ethnic cultures... 535-557 DOI: http://dx.doi.org/10.46925//rdluz.34.29

Since 1861, emancipated generations began to emerge, on whose shoulders the flame of the Russian Renaissance flared up. This terminology is used by both Russian philosophers and cultural scientists, in particular N.A. Berdyaev (Berdyaev, 1990) and D.S. Likhachev (Likhachev, 1985). There is one more important methodological addition, which will possibly strengthen and make the identification of the Renaissance distinct, for which the same N.I. Konrad. In whose works, according to contemporaries, it is difficult to separate the Middle Ages from the Renaissance in the East. This is the emerging bourgeois socio-economic formation, which has presented itself to the world as a paradigm of modernity, which is coming "on the heels" of the European Renaissance. For the Renaissance East, this addition naturally somewhat diminishes attention to the "Eastern Renaissance", therefore, another criterion of Renaissance should become a methodological addition, carried out from the standpoint of the ontology of the culture in question, which we propose, explicating it on the example of the ethnic culture of the Yakuts (the self-name of the people is Sakha).

What can become a universal criterion for the Renaissance? The usual analogies of the content aspects of the Renaissance are often contradictory or completely absent due to the unique uniqueness of historical events (Berdyaev, 1923). We believe that the essential criterion of the Renaissance can be considered the ability of a culture to master the symbolic and metaphysical apparatus of a certain culture, often lost culture of the past. In other words, the ability of a culture to master the symbolic form of another culture or an autonomous exit to a new symbolic nature is the defining criterion of the Renaissance. In European culture, it coincided and to some extent intensified the socio-economic change of social formations.

Thus, the rejection of the iconic formalism of culture and the return to the symbolic, compensating for the "loss of the culture of connection with the primary conditions of symbolization of consciousness" (Mamardashvili and Pyatigorsky, 1997: 192-193), a kind of symbolic archaization of culture, as M.K. Mamardashvili and A.M. Pyatigorsky, in fact, is a criterion for the renaissance of culture. Analysis of parallels carried out by N.I. Konrad confirms what was said in the language of the history of cultures. He writes in his work "Renaissance": "the rebirths of China and Italy converge, which means that the struggle to free the human intellect from the shackles of dogmatism - religious in Italy, philosophical in China - constitutes 
REVISTA DE LA UNIVERSIDAD DEL ZULIA. 3ㄹe época. Año $12 \mathrm{~N}^{\circ}$ 34, 2021

A. G. Pudov \& M. I. Koryakina// Parallels of cultural renaissance and dynamics of ethnic cultures... 535-557

DOI: http://dx.doi.org/10.46925//rdluz.34.29

the main ideological feature of the Renaissance in the region" (Konrad, 1966: 252). The Renaissance campaign against dogmatism, exegesis and scholasticism with the identification of new rationality, in the words of a historian and philologist of oriental texts, was the essence of isomorphic cultural processes called the Renaissance. The same thing in philosophical terminology sounds like an attempt to reanimate the meanings of culture through familiarizing with symbolic consciousness, which means a return in such an ontology to man, recorded in the anthropocentrism of the Renaissance. In the East and West, it sounded like the formula "ren=humanitas" (Konrad, 1966: 256).

\section{Methodological foundation}

Therefore as a methodological approach, we will use the term "rebirth" in the sense of removing the totality of the sign, and hence dogmatism and scholasticism, revealing the symbolic layer of a productive metaphysical culture that gives rise to a new rationality. At the same time, it should not be forgotten that as the totality of the sign is removed and the symbolic foundation of productive culture emerges, art, the aesthetic experience of the symbolic, becomes a tool. In this process, the symbolic apparatus of religious teaching is lost or distorted under the pressure of secularization and emancipation of anthropocentrism of the revivalist sense, a return to the pagan takes place. This is clearly recorded in the history of Russia with Orthodox Christianity at the beginning of the 20th century and in the history of aesthetic reminiscences in art. This is a return on the aesthetic wave to the secondary mythologically conceived symbolism (Konrad, 1966).

The methodological approach in our study appeals to the ontological criterion of the Renaissance culture, the ability of a given culture to operate with the symbolic constructs of another culture, its symbolic consciousness. This is an authentic way of rediscovering symbolic nature as opposed to sign culture, it is a way of multiplying one's own culture with new forms through aesthetic and philosophical reflection.

The strategy of our research comes to the fact that the enumerated substantive aspects of the Yakut culture are revealed on vivid examples of style in modern cinema and art, there are shown the peculiarities of the cultural paradigm of ethnomodern in contemporary art of Yakutia. 
REVISTA DE LA UNIVERSIDAD DEL ZULIA. 3ㄹe época. Año $12 \mathrm{~N}^{\circ}$ 34, 2021

A. G. Pudov \& M. I. Koryakina// Parallels of cultural renaissance and dynamics of ethnic cultures... 535-557

DOI: http://dx.doi.org/10.46925//rdluz.34.29

Being made in parallel, deductive theoretical generalizations about the possibility of describing the bright ethno-regional cultural phenomena of Russia as a cultural renaissance, conclude that the ongoing cultural process of the national region can be identified as the Silver Age of Yakut culture, having drawn a semantic parallel to the Russian Silver Age as a reflected European Renaissance.

\section{Results}

The relatively short era of the European Renaissance, refracted by Russian culture, an even more compressed spring of spiritual tension, splashed out a galaxy of prominent world stars, repeating in basic coordinates an interest in art and science, as it happened in the European Renaissance with emancipation and secularization, interest in anthropocentric humanistic ideas, non-scholastic education, scientific and technical creativity and the corresponding worldview, the playing in Russian culture of all significant styles of art that followed from the Renaissance - from baroque to realism.

The high intensity of cultural tension, set by the flight of art thought and embodied by scientific and technical creativity, was expressed by Russian literature through "rebellious modernity", hope, despair, expectation of changes to freedom. The "Golden Age" of Russian literature and poetry was supplemented by world classics: A.P. Chekhov, B.L. Pasternak, A.I. Kuprin, I.A. Bunin, D.S. Merezhkovsky, M. Gorky, Z.N. Gippius, V.S. Soloviev, V.Ya. Bryusov, K.D. Balmont, A.A. Blok, A. Bely, F.K. Sologub, L.N. Andreev, N.S. Gumilev, A.A. Akhmatova, O.E. Mandelstam, V.V. Mayakovsky, S.A. Yesenin, M.I. Tsvetaeva, A.N. Tolstoy. It is worth mentioning the phenomena of the Russian drama theater, Diaghilev's Russian ballet and the music of the "Russian ethnomodern". Prominent world scientists and technicians from Russia became an undoubted addition (Aronov, 2020).

At the same time, the Russian Renaissance in the literary metaphor is no longer "golden", but "silver age. It is dominated by a secondary value and an indication of decline. Leaving Russia, Berdyaev noted: "that after the Renaissance comes the "new Middle Ages" fraught with a sharp rollback, the death of cultural values and the foundations of civilization, the apotheosis of reaction and obscurantism, persecution of intellectuals and cultural figures, the collapse of 
humanism, escalation of violence and terror" (Kondakov, 2018: 429). The analogy with the European counter-reformation can be drawn here quite transparently. Berdyaev in his writings reveals the potential contradiction of the humanism of the Renaissance, stating a natural decline after the spiritual rise: "the possibility of self-denial of a person and his fall lurked in the very fundamental principle of humanistic faith ... a person broke away from the spiritual center of life, he broke away from the depths and moved to the periphery" (Berdyaev, 1923: 23).

Decadent thoughts appear in the tension of the hopelessness of civilizational backwardness and the high aspiration of a symbolically filled culture. These were words that convey the impotence of reason and consciousness in front of the inertia of the tradition, which is entrenched in the subconsciousness and mentality of the masses.

So, F. Sologub wrote:

"We are captive animals,

We vote as best we can.

The doors are deafly locked, And we dare not open them"

(Sologub, 1908).

Peter's the Great modernization in the next two centuries could not overcome the medieval feudal essence of Russian civilization. The subject of modernization was not formed, therefore, according to culturologists, "all subsequent stages of the cultural and historical development of Russia in the New Time were formal, artificially stylized and had the character of a secondary system (Kondakov, 2018: 415).

The metaphysical potential of the culture of European modernity began to be conquered by its own cultural forms precisely in the era of the Russian Silver Age. The culture of the Russian Renaissance was able, on its own cultural grounds, to "digest" European modernity and everything that had happened before it, producing new forms, modulated by the Russian symbolic spectrum of consciousness, which absorbed Orthodoxy and Russian folklore.

Attention should be focused on the process of cultural synthesis, where the synthesis of the symbolic was played within the framework of the aesthetic form. According to researchers of Russian ballet, it was the theatrical form that made it possible to effectively play out the synthetic function, combining the religious and philosophical symbolism of the era with the 
REVISTA DE LA UNIVERSIDAD DEL ZULIA. 3ㄹe época. Año $12 \mathrm{~N}^{\circ}$ 34, 2021

A. G. Pudov \& M. I. Koryakina// Parallels of cultural renaissance and dynamics of ethnic cultures... 535-557

DOI: http://dx.doi.org/10.46925//rdluz.34.29

pagan symbolism of the folk tradition: N.A. Benua expressed that “... our ballet is the most perfect synthesis of all existing arts" (Vedernikova, 2016: 109). In the plots of M.M. Fokin, V.F. Nijinsky successfully intertwined the religious ideas of the Symbolist poets, and the musical themes of I.F. Stravinsky absorbed the atmosphere of folk holidays and natural liturgy (Vedernikova, 2016). God-seeking with God-building, on the one hand, is neo-paganism, on the other, it is a synthetic result of Russian Renaissance. This is a confirmation of the return to life of the living sources of Russian culture, which continues to draw them to this day from the symbolic sources of folklore and living Orthodoxy, encoded in the symbol of faith.

At the same time, as noted, the Russian Renaissance opened up an abyss that opened a civilizational gap as a result of "skipping the Renaissance as a stage in the normal cultural and historical process in Russia. Here is the gap between the West and the East, between freedom and slavery, between the Enlightenment and the despotism of autocracy, between the people and the intelligentsia" (Kondakov, 2018: 430). Petr Chaadaev stated: "Once a great man ... threw us a cloak of civilization; we raised our cloak but did not touch enlightenment. Another time, ... returning home from a triumphal march through the most enlightened countries of the world, we brought with us only bad ideas and disastrous delusions, the consequence of which was an immeasurable disaster that threw us back half a century. We have something in our blood that rejects any real progress" (Chaadaev, 1836). We still continue to build a cultural bridge over the "civilizational abyss" separating the Russian Renaissance of the Silver Age from the natural Renaissance missed by Russia (Kondakov, 2018:433). It should not be forgotten that a cultural program for the production of new higher values was laid in the poetry of the Symbolists, with a deep belief in the fact that it is art that is capable of renewing the worldview and life of people.

The figure of Chaadaev marked the questioning of a modern man who was destined to be born several decades ahead of schedule. However, he, in fact, anticipated the Russian Silver Age, Russian Art Nouveau in art, the fruits of which are still used all over the world. He could not yet see, but he sensed the impending tasks that Russian culture needed to solve. He began to solve them from the Silver Age, following a special path.

Spiritual flesh and being demanded, but the "muscles of culture" in terms of the educational level were not enough. It was then that the inner need for self-education arose. The 
REVISTA DE LA UNIVERSIDAD DEL ZULIA. 3ㄹe época. Año $12 \mathrm{~N}^{\circ}$ 34, 2021

A. G. Pudov \& M. I. Koryakina// Parallels of cultural renaissance and dynamics of ethnic cultures... 535-557

DOI: http://dx.doi.org/10.46925//rdluz.34.29

pathos of the lack of knowledge was transmitted to the national outskirts of Russia, becoming an impetus for the emergence of a national intelligentsia. It is worth mentioning their names, which chronologically coincided with the "cultural thaw" of the national regions of the Russian empire. Vasily Nikiforov, Prokopy Sokolnikov, Alexey Kulakovsky, Anempodist SofronovAlampa, Nikolai Neustroev, Gavril Ksenofontov, Semyon Novgorodov, Platon Oyunsky, Ilya Vinokurov, Isidor Barakhov, by the date of their arrival in the world, successfully coincided with this period in the history of the fatherland.

The main problem was the lack of mass education and the quality of higher education, including science and technology. At the level of zemstvos, ideas were voiced for the legal consolidation of universal primary education, which did not find support in certain circles. By 1914, there were 10 universities and 105 high institutes in Russia, a state textbook became a mandatory minimum, and acquaintance with the originals was not required. Talented students studied in several faculties. Self-education was in demand among young people, which took the form of self-education circles in secondary and higher educational institutions.

By the way, the need for self-education for a modern ethno-national region is becoming one of the important criteria for the renaissance of a culture experiencing overheating and in need of self-development and the production of new forms in which the ideas of a new generation would be realized. Today, we can state the presence of a "branch" cultural overheating, realized in the theatrical and cinematic life of Yakutia. These are the author's theater of Sergei Potapov, Yuri Makarov, the Olonkho theater, the successes of Yakut drama and cinema at international and all-Russian forums. There are high hopes for the cultural paradigm of ethnomodernism in Yakut art (Pudov, 2019).

When did the Yakut Renaissance happen, its "Silver Age" of culture? Or has he already imperceptibly slipped into the Yakut graphics of the 70s and 80s, the work of symbolist poets like Ivan Arbita, the successes of modern Yakut filmmakers on international platforms? Undoubtedly, sporadically, bright stars in the culture of Yakutia lit up representatives of the "Silver Age" during the 20th century in various forms of art.

Drawing parallels between the current state of Yakut culture and the culture of the Russian Renaissance and noting characteristic coincidences, we can state the onset of the "Silver 
REVISTA DE LA UNIVERSIDAD DEL ZULIA. 3ㄹe época. Año $12 \mathrm{~N}^{\circ}$ 34, 2021

A. G. Pudov \& M. I. Koryakina// Parallels of cultural renaissance and dynamics of ethnic cultures... 535-557

DOI: http://dx.doi.org/10.46925//rdluz.34.29

Age" of Yakut culture. Fine arts, theater, the Yakut film boom, the successes of Yakut cinema in recent years, the source of which is not only increased skill and objective technical capabilities, which cannot be ignored, but rather a passionate surge of culture, which, by the way, can scatter. Art workers act in these avant-garde forms according to an internal message, which is read from the tension of ethnic culture. The latter gives them this quality. Here passionarity is an irrationality similar to that described by L.N. Gumilev in his theory (Gumilev, 2019), but he had it as a biological force of natural origin. In this case, the passionarity of culture as a supranatural spiritual system that turned its gaze from the conquered position of modernity to the symbolic capital of the traditional era, disappearing under the pressure of mass culture of unifying globalism of the world capitalist system and leaving a feeling of the disappearance of something important in the life of a modern ethnophor.

If we talk about the qualitative assessment of "cultural renaissances", the Russian cultural renaissance of the late 19th and early 20th centuries became a symbolic synthesis of European modernity with Orthodoxy and Russian folk culture. The Yakut Silver Age or the Yakut Cultural Renaissance (Pudov, 2020) is based on the synthesis of European modernity and ethnocultural symbolic forms of the Sakha people, its ethno-symbolic capital. We call the latter the conservative bosom of the national culture. It is, it was and should be preserved. Its main function is protective, it remained for the ethnos as a legacy of ancestors, the cultural basis of traditional and modern society. In cultural discourse, it is also called the "genetic code of culture" or simply "the code of culture". It is interesting to note that ethno-symbolic capital, some kind of unknown knowledge, manifests itself more vividly as the "ethnic person" develops modernity. This is how the constructive possibilities of one's own and foreign culture are revealed.

The West, experiencing an acute spiritual crisis, is "subconsciously" interested in institutions capable of reproducing traditional values. There are almost none of them left. Therefore, the West is interested in the lost experience of cultures that still preserve traditional values in the 2lst century. These are societies that have preserved elements of the traditional way of life and beliefs, which means a mythological worldview (before- and pre-modern). Success on international venues in the field of art, in particular cinema, confirms this fact. Therefore, cinema, as well as theater, performing a protective function for traditional 
REVISTA DE LA UNIVERSIDAD DEL ZULIA. 3ㄹe época. Año $12 \mathrm{~N}^{\circ}$ 34, 2021

A. G. Pudov \& M. I. Koryakina// Parallels of cultural renaissance and dynamics of ethnic cultures... 535-557

DOI: http://dx.doi.org/10.46925//rdluz.34.29

institutions, at the same time becoming an ethnocultural avant-garde, designated ethnomodern (Pudov, 2019a; Pudov, 2019b).

According to culturologists, Russia at an accelerated pace passed the main cultural stages of Europe, reflecting in stylization at the level of mass culture the styles of baroque, classicism, sentimentalism, romanticism, realism, etc. In the case of the evolution of the Yakut art and culture of the 20th century, these styles of art were "converted" into types of art and culture, which became a cultural avant-garde at each stage of self-development. These are literature, theater, music, painting, sports, graphics, premodern theater, ethnomodern theater, fine arts, cinema, these styles "losers" in themselves.

The main criterion for attributing art forms to the Yakut Silver Age was for us the belonging of works of these types to the cultural paradigm of ethnomodernism. The latter can be called a productive part of modern Yakut culture. What is its nature? Sakha were able to master modernity, and through this intuitively feel the advantages of their ethnic, let us note the symbolic culture, and at the same time reflect on the weaknesses of modernity and the futility of a totally desymbolic postmodernity. Therefore, ethnomodernity is seen as the ability to intensify ethnocultural symbolic capital, the development of its cultural capabilities, taking into account the use of forms of modern culture. At the same time, the symbolic capital of ethnic culture "appreciates" nature-proportionality, environmental friendliness, morality, health and life-giving physical capacity. The ability to operate with the symbolic opens up the possibility of creating a culture, even one that is alien in quality. This is the criterion for its development. Ethnomodernism is at the same time a new version of socio-cultural modernization, different from the usual models of modernization (Fedotova, 2000).

What does ethnomodernity do? Philosophers have a term "large thought of nature", such, for example, is the idea of a "wheel", which carries in its horizon of thought the absolute principle of movement and the symbol of solarity. A major thought for the North, in addition to the moral universals of tradition, can be "northern nature", which sets the horizon of thoughts like snow, ice, water, frost, fog, the natural bosom of human life, their harmonious coexistence, but also expanding this range to new ideas. In other words, the Yakut Silver Age and the ethnomodern 
REVISTA DE LA UNIVERSIDAD DEL ZULIA. 3ㄹe época. Año $12 \mathrm{~N}^{\circ}$ 34, 2021

A. G. Pudov \& M. I. Koryakina// Parallels of cultural renaissance and dynamics of ethnic cultures... 535-557

DOI: http://dx.doi.org/10.46925//rdluz.34.29

paradigm reveal the possibility of living in a value-semantic space, born today by the very same ethnoculture.

Summarizing, we can say that the criterion of the renaissance of the Yakut culture, its "ethnomodernity" is the ability to unpack and make spiritually and materially useful ethnosymbolic capital in modern life (Pudov, Koryakina et al. 2020). The way to intensify the symbolic capital of ethnic culture, to develop its culture-producing capabilities in the current conditions of mixing modernity, postmodernity and altermodernity expresses the renaissance of a particular culture.

A striking manifestation of ethnomodernism in the worldview can be, for example, the advancement in culture of the phenomenon of cold, which from time immemorial carried a respectful but negative connotation among the Sakha ancestors, opposing the traditional values of heat, light, the sun and natural abundance. In other words, this is the transformation of natural sagacity and observation into the potential of an unusual economy, and then the economy. The perception of the idea of "cold" as a constructive concept becomes a criterion for the development of modernity. The impossibility of perceiving such concepts is an indicator of the presence of a conservative, traditional worldview for an ethnos. In the Eurocentric paradigm, this is given by a constructive assessment of the technogenicity and innovativeness of culture, which was not the case in the traditional era among the Yakuts.

In connection with the above, the rise of the Yakut cinema is more than the technical equipment or the increased skill of regional filmmakers, the mastery of the external, iconic side of modernity. Primary is the state of regional culture, which is experiencing a passionary upsurge, the essence of which is the aforementioned assimilation of modernity at the level of metaphysics of its symbolic forms and the preservation of the symbolic capital of ethnic culture, which is necessary for its transformation into sociocultural capital and the social code of the modern ethnos and its culture.

Not every modern Yakut filmmaker can be called representatives of ethnomodernity in cinema. It is necessary to have certain qualities - having absorbed the traditional, to be receptive to the universal, subtly feeling the rift in the regional culture. Not everyone fits into this form either by age, not caught up in tradition, or insensitive to the creative potential of modernity. 
REVISTA DE LA UNIVERSIDAD DEL ZULIA. 3ㄹe época. Año $12 \mathrm{~N}^{\circ}$ 34, 2021

A. G. Pudov \& M. I. Koryakina// Parallels of cultural renaissance and dynamics of ethnic cultures... 535-557

DOI: http://dx.doi.org/10.46925//rdluz.34.29

Nikita Innoketyevich Arzhakov was originally a man of the theater, retrained at VGIK. He had government orders from the Sakhafilm film company, full-length heartfelt stories about the war, a portrait of the Yakut generation of the 20th century in artistic and documentary performance.

Nikita Arzhakov's new work, "Tygyn Darkhan" in 2020, addressed the task of returning the original cultural codes of the Sakha people. The film fits into the paradigm of a conservative ethnomodernism, realized through a plot immersion in the traditional era, washing away all modern connotations and clearing the space for building an original construct that revives lost meanings. The film has become a kind of time machine that transports the viewer into the era of feudal fragmentation at the turn of the 16th-17th centuries and is sharpened to trigger longdormant meanings in the subconscious of the Sakha viewer, which return him to understanding of his place and role in modern life. Genre film meditation is designed for the Yakut viewer, who must remember what he "knew" for a long time at the level of cultural memory but was not aware. Cinema, in the role of a modern form of culture, having absorbed the ethnosymbolic spectrum, realizes the reanimation (Pudov, 2014) of its meanings in the minds of the modern viewer.

Sergei Stanislavovich Potapov in his films "Small Motherland - Doydu" and "The Deity of the Horse - Desegei Aiyy" uses the expansion of mythological consciousness and the corresponding sociocode with universal symbolic constructs - philosophy and Christianity. The cinema form designed by the author allows to experience the new in the passing everyday life. This topic can be described as the fate of a culture that did not have time to digest the rapid pace of the era. The author has realized the aesthetics of ethnomodern synthetic symbolism. The author's technique was to use the attributes of the material and spiritual culture of the Sakha, presented in the rituals and ceremonies of the summer holiday Ysyakh, introduced into the new metaphysical space created by cinema. There was a symbolic overlap with plots from the Gospel, a new understanding of the meanings of Yakut culture was born, capable of synthesizing universal metaphysics from the mythological tradition.

Sergei Potapov went through the school of acting, theater directing in Moscow with Mark Zakharov. He is a representative of the author's cinema of Yakutia. Freedom of a creative 
REVISTA DE LA UNIVERSIDAD DEL ZULIA. 3ㄹe época. Año $12 \mathrm{~N}^{\circ}$ 34, 2021

A. G. Pudov \& M. I. Koryakina// Parallels of cultural renaissance and dynamics of ethnic cultures... 535-557

DOI: http://dx.doi.org/10.46925//rdluz.34.29

person in the special conditions of a breakdown in the socio-cultural environment is an existential task that the director solves in regional art, testing the theme of combining the universal language of the soul and national mentality. The synthesis of the latter gives rise to new cultural opportunities, serves as an instrument for preserving the ethnic symbolic spectrum, which is finding a living bosom in mass culture. Potapov drew a parallel between the viscous ideological subconscious and rational conscious experience. Conceptual searches for the metaphysical go through the director's work in the Yakut synthetic art. Embodying the modern generation of artists, the director made a successful attempt to conquer a cultural space that transcends the echoes of the ideological. Tragic fun, special Potapov's irony and skillful telescopic approximation of the historical past became his tools and hallmark.

An example of the cinematic success of Yakutia at several international film festivals will seem remarkable. Eduard Novikov's film "The Tsar Bird" of 2018 refers to ethnopremodernity in our classification of aesthetic paradigms. In contrast to ethnomodernity, the borderline of ethnic premodernity is capable of arousing mass interest from other national cultures, reflecting on their pagan origin.

Based on the literary tradition of the "golden age" of Yakut culture, a galaxy of filmmakers has formed, who have staged their films based on the work of the Yakut literary classics. These are the founders of the cinema of Yakutia Alexei Romanov, Nikita Arzhakov, Prokopiy Nogovitsyn, Vyacheslav Semyonov and the young author Mikhail Lukachevsky. Separately, mention should be made of the names of those who took up cinematic reflections from the perspective of the conquered modernity to the outgoing era of traditions. Playwrights and screenwriters Aisen Doydu and Semyon Ermolaev became a prominent representative of this phenomenon. The directors of this niche include Tatyana Everstova, Lyubov Borisova, Prokopiy Burtsev and others.

Yakut horror and mystic films deserve special mention in revealing a specific mythological layer of Yakut culture. This is an inexhaustible source of creative inspiration for Sakha, seasoned with the fears of a modern layman. Films become a kind of excursion into the Yakut subconscious, which is inhabited by mythological characters from the other world and this world. These films can be included in the cultural paradigm of ethnopremodern and 
REVISTA DE LA UNIVERSIDAD DEL ZULIA. 3ㄹe época. Año $12 \mathrm{~N}^{\circ}$ 34, 2021

A. G. Pudov \& M. I. Koryakina// Parallels of cultural renaissance and dynamics of ethnic cultures... 535-557

DOI: http://dx.doi.org/10.46925//rdluz.34.29

premodern. This paradigm should include some works by Alexei Romanov, Gennady Bagynanov, Anatoly Vasiliev, Elley Ivanov, Kostas Marsan, Stepan Burnashev, Procopius Burtsevand other, younger filmmakers.

Dmitry Davydov, known today in Russia, being a representative of Russian culture, but having absorbed from childhood the social codes and mentality of the Yakut culture, skillfully uses the elements of ethnomodernism, which are included in his films through the social life of the modern Yakut village in the film "Fire in the Wind" and "There is no God, except me "or charismatic characters, such as the ethnic singer Valentina Romanova-Chyskyyrai in the film "Scarecrow". Davydov's author's film studies always go along the fault line in Yakut culture between the disappearing tradition, shackled by social ailment and the "civilization" represented by the sociality of the Yakut village or city. Yakut cinema makes it possible to actively fund the ontological conquests of cultural paradigms - ethnopremodern and ethnomodern, revealing the potential for self-development of culture.

In connection with the above, the modern task is associated with solving the problem of preserving and prolonging the existence of an ontological basis in the issue of ethnic national identity. This is the task of "expanding the world" at the point of an ethnic symbol, namely, the need to combine ethnic symbolism with universal symbolism, represented in the conquests of the universal metaphysical culture of philosophy and world religions. The establishment of conjugations, the emergence of ethnic symbols into universal symbolism are the main cultural dominants in the era of leveling cultural globalism, in other words, the change from the stage of self-institutionalization to the stage of ethnocultural modernization. Globalism appears as a way of usurping symbolic forms, reducing their metaphysical significance and rank, down to the level of a sign, and the practice of outdated models of catch-up modernizations leads to secession and the growth of fundamentalist attitudes. In the era of global capitalism and cultural decline, we must oppose the free and all-round development of Russia's national cultures by developing the ethnic cultural capital of the peoples inhabiting the state, the basic basis of which should be socio-cultural modernization, conquering the achievements of modernity on its cultural grounds, returning to the West new meanings of modernity. 
REVISTA DE LA UNIVERSIDAD DEL ZULIA. 3ㄹe época. Año $12 \mathrm{~N}^{\circ}$ 34, 2021

A. G. Pudov \& M. I. Koryakina// Parallels of cultural renaissance and dynamics of ethnic cultures... 535-557

DOI: http://dx.doi.org/10.46925//rdluz.34.29

\section{Discussion}

Using the poetic allegory of the "silver of the age", one may ask, why is it not the "golden age"? We believe that the "golden age" in the Yakut culture should include an authentic ethnic culture with the spiritual heritage of the heroic epic Olonkho and material economic activities Yakut cattle breeding and herd horse breeding, hunting and fishing. If you try to stretch the Yakut golden age in time until the Soviet era of the 20th century, then it can be synchronized in a broad context with the beginning of active creative development and processing of the culture of Russian and European modernity not only in the field of art, but in the introduction to literacy, higher education, science, technology and Olympic sports. This should include the constellation of the first wave of the Yakut intelligentsia with literary and social creativity, almost coinciding in time with the Russian Silver Age even by date of birth, ending with the classics of the Soviet era, the period of the appearance of the great Yakut novel, scientific historiography, the Olympic triumph of Soviet Yakut wrestlers of the 70s.

Modern Yakut culture demonstrates the uniqueness of the presence of both modernity, ethnomodernity and premodernity. The originality of the Yakut ethnomodern lies in the synthesis, and not simply in the mixture of mythological and metaphysical. The synthesis gives rise to an ethnocultural renaissance that did not exist in history. The Russian renaissance of the Silver Age was a product of a synthesis of Orthodox Christianity, Russian folk culture and modernity. A similar quality occurred in the 15th-17th centuries in Europe, which in fact was a historically noticeable Renaissance symbolic production against the background of the dominance of scholastic medieval culture, the Renaissance, which returned to the philosophical symbolism of the ancient era, which held on to the "empty form" of three philosophical pillars, preventing the Greeks from assimilating into barbarians - the Olympic Games, the ancient theatrical tragedy and the question of a man who conquers a centaur in himself.

The advantages of an unspent mythological worldview of a traditional society for ethnocultures lies in the fact that it encoded the consciousness of the representatives of the ethnic group in the absolute coordinates of the morality of Good and Evil, while modern global culture, actively using the mythological method of coding society, relativizes absolute concepts, removing the moral component, replacing it with the ideologemes of the consumer society. 
REVISTA DE LA UNIVERSIDAD DEL ZULIA. 3ㄹe época. Año $12 \mathrm{~N}^{\circ}$ 34, 2021

A. G. Pudov \& M. I. Koryakina// Parallels of cultural renaissance and dynamics of ethnic cultures... 535-557

DOI: http://dx.doi.org/10.46925//rdluz.34.29

Do not forget that the ancient Greeks carried out a "zero cultural renaissance" on the substrate of their ethnic mythological worldview, producing not variations of mythological symbols of consciousness, but qualitatively new symbolic constructs, philosophical symbol forms.

Confirming the onset of the "Silver Age" of Yakut culture, one should also recall the decline of any renaissance. In the case of the Russian cultural renaissance, it was the emergence of a "gaping chasm between culture and civilization". The cultural renaissance ended with a revolution that clearly marked in its socialist stage the destruction of the symbolic nature of consciousness. It led to a distorted substitution of the formal-symbolic for literal cash. So, the symbolic metaphysics of Christianity began to be perceived not in its symbolic abstraction but replaced by the iconic reality of political ideology.

The destruction of the symbolic nature of ethnoculture for Sakha can occur under the pressure of assimilation by mass culture, the social codes of the global faceless postmodernism, which emasculates the moral basis of man. The breakdown that occurs after the "Silver Age" of culture can be weakened by opposing the pop culture industry, in addition to the creative industries of ethnomodernism and the conservative symbolism of tradition, the social form of the institution. This is the need for socio-cultural practice, a practiced social cult of a metaphysical order, supplemented by a new social normative ethical sense.

In the aggregate of the results the regional ethnoculture is experiencing counterdirectional currents. At the same time, the counterproductive cultural assimilation that all ethnic cultures of Russia experience under the influence of mass culture is significant. Meanwhile, there are conservative and productive trends:

a) the preservation of ethnic symbolism (Pudov, 2014) both in contemporary art forms, and its consolidation in traditional folklore genres;

b) the transformation of ethnosymbolism in modern forms of culture.

Counter directional assimilation and conservation have formed a cultural rift. Thus, the mass culture of industrial civilization is semiotic (iconic), and the traditional agrarian culture is symbolic. In principle, a rift arose in any culture and was traced back to the times of Ancient Greece, when, for example, the mythological tradition already split by the metaphysics of 
REVISTA DE LA UNIVERSIDAD DEL ZULIA. 3ㄹe época. Año $12 \mathrm{~N}^{\circ}$ 34, 2021

A. G. Pudov \& M. I. Koryakina// Parallels of cultural renaissance and dynamics of ethnic cultures... 535-557

DOI: http://dx.doi.org/10.46925//rdluz.34.29

philosophy could follow the path of Socrates-Plato (the symbolic nature of consciousness) or the path of Aristotle (the iconic nature of consciousness). The culture has chosen the second option - an iconic (Mamardashvili and Pyatigorsky, 1997).

With the total expansion of the symbolic formalisms of culture, a kind of "reset" or revitalization of the living principles of culture takes place by turning to symbolic form, often through religious and philosophical practices, art and even physical exercises, for example, in yoga.

The general institutional interest in the symbolic gives rise to new cultural forms, which we call the cultural renaissance. It happened in the opinion of Russian culturologists (Aronov, 2020; Kondakov, 2018) in Russia at the turn of the 19th and 20th centuries, in the East at the middle ages (Konrad, 1966), but it can happen "compactly" and not so vividly, within the framework of the ethnocultural complexes of modern Russia, which we illustrated by the example of the culture of the Sakha people at the turn of the 20th - 21st centuries.

Flexible multinational forms of Russian culture are vital than the proposed Western models of multiculturalism (Zhizhek, 2005). The world of globalist profit-making cannot in principle produce them, offering only "digital totalitarianism". Russian culture can draw strength through the creativity of regional Russian cultures. The implicit potential of multinationality can be claimed through ethnocultural practices. Until now, multinationality has been held together by the ideas of paternalism and statehood. The power that feeds the culture of Russia must come through the gathering of streams of modernized ethnocultural multinationality.

Historically, the Russian egregor was in the spreading of the power of the statist-type state from the metropolis. Now, the rays of culture must come from the regions and they go, which have historically accumulated this spreading force, absorbing modernity, making it their own being and feeding the wasted Russian egregor through their roots. In a cultural context, ethnocultural regions will be able to return to Europe the meanings of modernity, which have been partially forgotten or wasted by the carnival and empty postmodernism. This is one of the most important functions of any cultural renaissance. 
REVISTA DE LA UNIVERSIDAD DEL ZULIA. 3ㄹe época. Año $12 \mathrm{~N}^{\circ}$ 34, 2021

A. G. Pudov \& M. I. Koryakina// Parallels of cultural renaissance and dynamics of ethnic cultures... 535-557

DOI: http://dx.doi.org/10.46925//rdluz.34.29

Modern and postmodern are in fact an expression of the urbanism of the urban lifestyle, its socio-cultural ties. Ethnomodernity in this vein is a product and result of "rural" modernity in the urban environment. Urban Yakuts who have lived since birth or have recently moved to the city are "spiritually" comfortable in the city because they have a "rear" as a village. Relatives live there, nourishing their cultural roots with various ties. If the village weakens and it does not have a tide of youthful strength, the rear will disappear, the roots will dry up, and the ethnic culture will assimilate and disappear in the urban environment in one generation.

Currently, a number of interesting processes are taking place in the culture of Yakutia, which draw attention to themselves with their expressiveness, primarily in art, and affect the cultural state of the Yakut ethnos. In the humanities, they are not clearly recorded or recognized. Defining this phenomenon, the author proceeds from a comparative analysis, drawing parallels with the Russian Silver Age, finding qualitative isomorphisms in the cultural dynamics of the Yakut ethnic group. Since 2000, researchers have drawn parallels between modern Yakut poetry and the poetry of the Silver Age at the turn of the 19th-20th centuries, and it has been identified as the Silver Age of Yakut poetry (Bugaev, 2000).

The author sets tasks with fixing important events of the Yakut culture, reflecting its dynamics and identified in early works. The cumulative task is associated with identifying the advantages of having a productive ethnoculture over the trend of universalization by the culture of the global world, the controversial aspects of modernity and postmodernity.

\section{Conclusion}

The ethnic cultures of Russia are faced with a Global Challenge of cultural globalism, about their place and right to exist in the modern world. In the presented material, the author brings together the qualitative trends in the self-development of the Sakha culture, defining its qualitative components - premodern and ethnomodern.

1. The main result of the analysis is the statement of the state of culture, identified as the "Yakut Silver Age", carried out by analogy with the Russian Silver Age, which symbolizes the onset of a cultural renaissance against the background of cultural globalization de-symbolizing ethnic cultures. This is the result of a double reflection of the cultural renaissance of the 
REVISTA DE LA UNIVERSIDAD DEL ZULIA. 3ㄹe época. Año 12 N 34, 2021

A. G. Pudov \& M. I. Koryakina// Parallels of cultural renaissance and dynamics of ethnic cultures... 535-557

DOI: http://dx.doi.org/10.46925//rdluz.34.29

European Renaissance and the Russian Silver Age on the authentic soil of pre-modern Yakut ethnic culture.

2. The criteria for the latter is the presence of a creative paradigm of ethnomodernism, manifested in the field of art. The analysis of the indicated state makes it possible to assess the possibility of disrupting the cultural renaissance and the factors influencing this event in one way or another.

3. The conditions of the cultural renaissance are the presence of mass culture of unifying globalization, which in the language of symbolology is a consequence of the total semiotization of culture and the weakening of the metaphysics of symbolic forms. Metaphorically, it is a protest of the symbolic nature of man against the totality of an all-pleasing and extra-ontological sign. The cultural renaissance is a wavy cyclical process of changing the cycle of total semiotization in culture to a cycle of symbolization.

4. The breadth of the symbolic spectrum of culture, based on the presence of metaphysical symbolism, is responsible for the influence on the surrounding cultural landscape and the ability to cause its own reflected cultural renaissance in it. The presence of the metaphysical symbolism of philosophical knowledge provides the most powerful transformative effect on contact cultures inducing their own cultural renaissance.

5. The result of the study of the topic is the fact that an ethnic person is able to return the meanings of modernity to European culture itself at era of globalism with dominated postmodernism. This is explained by the human susceptibility of the ethnomodern paradigm to two traditions, two cultural paradigms - mythological "premodern" and metaphysical "modernist". The preservation of the institutions of the tradition of premodern, the involvement and assimilation of the tradition of modernity is a transitive mechanism for the transmission of cultural traditions of symbolic consciousness, a way of deconstructing the culture of an allpleasing extra-ethical sign.

\section{References}

Aronov, A.A. (2020). The turn of the 19th and 20th centuries: Golden or Silver Age of Russian Culture? Bulletin of KAZGUKI, 2, 7-9. 
REVISTA DE LA UNIVERSIDAD DEL ZULIA. 3ㄹe época. Año $12 \mathrm{~N}^{\circ}$ 34, 2021

A. G. Pudov \& M. I. Koryakina// Parallels of cultural renaissance and dynamics of ethnic cultures... 535-557

DOI: http://dx.doi.org/10.46925//rdluz.34.29

Berdyaev, N.A. (1923). End of the Renaissance (towards the modern crisis of culture). Retrieved from http://www.odinblago.ru/konec_renessansa

Berdyaev, N.A. (1990). Russian idea. The main problems of Russian thought of the 19th century and the beginning of the 20th century. On Russia and Russian philosophical culture: Philosophers of the Russian post-October abroad. Moscow: Nauka.

Bugaev, N.I. (2000). National originality of poetry: the example of Yakut poetry (Doctoral dissertation). Yakutsk.

Chaadaev, P.Ya. (1836). Philosophical letters. Retrieved from http://az.lib.ru/c/chaadaew_p_j/text_0010.shtml

Chaloyan, V.K. (1963). Armenian Renaissance. Moscow: Publishing house of the Academy of Sciences of the USSR.

Fedotova, V.G. (2000). Typology of modernizations and methods of their study. Problems of Philosophy, 4, 3-27.

Gumilev, L.N. (2019). Ethnogenesis and the Earth's biosphere. Moscow: Airis-Press.

Kondakov, I.V. (2018). Russian mass culture: from baroque to postmodernity. Saint Petersburg: Center for Humanitarian Initiatives.

Konrad, N.I. (1966). About the Renaissance.West and East. Moscow: Main edition of oriental literature, 1966. 240-281.

Konrad, N.I. (1966). West and East: articles. Moscow: Main edition of oriental literature.

Kulizade, Z. (1983). Regularities of the development of oriental philosophy of the 13-14th centuries (region of Islam) and the West-East problem. Baku: Elm Publishing House.

Likhachev, D.S. (1985). Russian Pre-Renaissance in the history of world culture (synopsis of the concept). The past is the future. Articles and essays. Leningrad: Nauka.

Losev, A.F. (1978). Aesthetics of the Renaissance. Moscow: Mysl.

Mamardashvili, M. K., Pyatigorsky, A. M. (1997). Symbol and consciousness. Metaphysical reasoning about consciousness, symbolism and language. Moscow: School "Languages of Russian culture".

Nutsubidze, Sh.I. (1967). Rustaveli and the Eastern Renaissance. Tbilisi: Literature and Helovneba.

Platonov, O. (1997). History of the Russian people in the 20th century. Retrieved from http://lib.ru/PLATONOWO/russl.txt 
REVISTA DE LA UNIVERSIDAD DEL ZULIA. 3ㄹe época. Año $12 \mathrm{~N}^{\circ}$ 34, 2021

A. G. Pudov \& M. I. Koryakina// Parallels of cultural renaissance and dynamics of ethnic cultures... 535-557

DOI: http://dx.doi.org/10.46925//rdluz.34.29

Pudov, A.G. (2019a). Identification of the productive paradigm of the artistic culture of Yakutia. Observatory of Culture, 16 (3), 251-262. https://doi.org/10.25281/2072-3156-2019-16-3-251-262

Pudov, A.G. (2019b). Ethnomodern is a new creative paradigm of the artistic culture of Yakutia. Tambov: Diploma, 4, 117-121. https://doi.org/10.30853/manuscript.2019.4.24

Pudov, A.G. (2011). Key paradigms of coding social reality. Historical, philosophical, political and legal sciences, cultural studies and art history. Questions of Theory and Practice, 5 (11), 161166.

Pudov, A.G. (2020). Cultural parallels of the Renaissance: representatives of the European and Russian Renaissance. Yakutsk Philosophical Journal, 3 (8), 4-10.

Pudov, A.G. (2018). Symbolic explication of the evolution of ethnoculture: the example of the Sakha people. Philosophy and Culture, 1, 32-38. DOI: 10.7256/2454-0757.2018.1.25165

Pudov, A.G. (2014). Aesthetics of the symbolic in the era of transitive social reality. Yakutsk: RIO media-holding.

Pudov, A.G., Koryakina, M.I., Yakovleva, E.P., Efimova, L.S., Shkurko, N.S. (2020). Construction of modern ethno-cultural identity by symbolic art forms as a condition for self-development of culture: on example of Yakutia (Siberia, Russia). Rupkatha Journal on Interdisciplinary Studies in Humanities, 12(4), 2-14. DOI: 10.21659/rupkatha.vl2n4.15

Sologub, F. (1908) The captive animals. Retrieved from https://www.culture.ru/poems/22500/plenyonnye-zveri.

Vedernikova, M.A. (2016). Ballet in the context of religious and philosophical searches of the Silver Age. Bulletin of MGUKI, 1 (69), 107-112.

Voskresenskaya, M.A. (2015). The Silver Age and the Russian Renaissance: on the Content and Correlation of Concepts. University Scientific Journal, 14, 32-43.

Zhizhek, S. (2005). Interpassivity. Desire: attraction. Multiculturalism, St. Petersburg: Aletejya Publ. 